\title{
Implementasi Forward Chaining dan Metode Simpleks untuk Menentukan Ransum Unggas yang Ekonomis
}

\author{
http://dx.doi.org/10.28932/jutisi.v6i1.2320 \\ Wildan Mahmud ${ }^{\bowtie 1}$ \\ \# Program Studi S1 Sistem Informasi, STMIK KADIRI \\ Jl. Balowerti 2 No. 26-30 Kediri 64121 \\ ${ }^{1}$ wildan.mahmudegmail.com
}

\begin{abstract}
Poultry needs food to maintain their lives and to ensure reproduction. To meet the needs of these nutritional elements, poultry eat from various types of food. Because there is no single food ingredient that contains a complete nutritional element, so we need a variety of appropriate and balanced food ingredients to meet nutritional needs. This can be done by choosing cheap food ingredients without ignoring the quality of the nutritional content that is adjusted to the type and age of poultry. To solve the problems, an expert system with a forward chaining method can be used to determine the nutritional needs and nutritional content of food ingredients. Linear programming with the simplex method is used to determine the combination of poultry feed-forming ingredients that meet economical poultry nutritional needs. The results showed that the cost of a combination of poultry feed ingredients was 3572.37 for starter phase laying hens. From the food ingredients of corn, bran, and fish meal, it turns out that the combination of bran and fish meal has adequate nutritional content with coefficients of 0.5 and 0.3 .
\end{abstract}

Keywords- Forward Chaining; Poultry; Ration; Simplex Method;

\section{Pendahuluan}

Setiap makhluk hidup, termasuk unggas memerlukan makanan untuk mempertahankan hidupnya serta untuk berproduksi. Meskipun makan kenyang belum tentu sehat dan produktif. Untuk memenuhi kebutuhan unsur-unsur nutrisi tersebut, unggas makan dari berbagai jenis makanan. Oleh karena tidak ada satupun bahan makanan yang mengandung unsur nutrisi secara lengkap, sehingga diperlukan berbagai ragam bahan makanan yang tepat dan seimbang untuk memenuhi kebutuhan nutrisi. Selain itu ketersediaan bahan makanan juga harus diperhatikan karena tidak semua bahan makanan yang dibutuhkan dalam pembentukan ransum tersedia secara terus menerus.

Unggas yang dipelihara untuk keperluan produksi biasanya dikandangkan, sehingga kebutuhan pangan atau nutrisinya tergantung pada pakan atau ransum yang diberikan. Kecukupan nutrisi unggas ditentukan oleh kualitas ransum dan cara pemberian ransum yang baik untuk menjaga atau meningkatkan produktifitas. Biaya produksi peternakan sebesar $60 \%$ sampai $80 \%$ untuk mencukupi ransum [1]. Besarnya biaya produksi tersebut dapat menyebabkan peternak unggas merugi. Oleh karena itu untuk menekan biaya pakan, peternak dapat menyusun ransum secara mandiri dengan terlebih dahulu memeriksa kandungan nutrisi dan harga tiap bahan pakan yang akan dikombinasikan dan kemudian melakukan evaluasi ransum yang diberikan dapat memenuhi kebutuhan nutrisi unggas [2].

Membuat ransum berdasarkan kebutuhan nutrisi yang perlu diperhatikan dalam menyusun ransum adalah ketersediaan bahan, kualitas atau kandungan nutrisi, serta cara penyimpanan. Penyusunan kombinasi bahan makanan harus memperhatikan pemenuhan kebutuhan nutrisi dan nilai ekonomi yang tinggi. Hal itu dapat dilakukan dengan memilih bahan makanan yang murah tanpa mengabaikan kualitasnya dengan kandungan nutrisi yang disesuaikan dengan jenis dan umur unggas [3, 4].

Penelitian Hilmi [5] tentang ransum unggas membahas sistem informasi tentang harga ternak dan harga pakan unggas untuk tingkat grosir dan eceran yang digunakan dinas peternakan memantau harga ternak dan pakan unggas. Maksudi [6] membahas tentang perhitungan ransum unggas yang dapat memformulasikan ransum secara otomatis sehingga dapat menghitung kandungan nutrisi yang dibutuhkan oleh tiap-tiap kategori umur ayam, perkiraan biaya pakan, dan stok bahan pakan yang tersedia. Retnasari [7] yang meneliti pakan unggas pada agribisnis peternakan unggas dari sudut pandang sistem basis data. Ardhi [8] dan Suwirmayanti [9] membahas metode simpleks untuk optimasi jumlah kalori makanan yang dibutuhkan dalam menu diet. Tujuan penelitian tersebut adalah menentukan berat makanan dan dapat meminimalkan biaya dengan 
kebutuhan gizi yang terpenuhi. Adinegoro [10] membahas tentang optimasi biaya pemenuhan asupan gizi pada makanan bagi anak-anak. Tujuannya adalah mencari komposisi jenis dan jumlah makanan yang dapat memenuhi kebutuhan anak-anak dengan biaya seminim mungkin.

Dari penelitian yang telah dilakukan sebelumnya, penelitian ini menyelesaikan permasalahan ransum unggas yang ekonomis sistem pakar dengan metode forward chaining dapat dimanfaatkan untuk menentukan kebutuhan nutrisi menurut jenis dan umur unggas dan kandungan nutrisi bahan makanan pembentuk ransum [11], sedangkan pemrograman linier dengan metode simpleks digunakan untuk menentukan kombinasi bahan makanan pembentuk ransum unggas yang memenuhi kebutuhan nutrisi unggas dan ekonomis [12]. Pemanfaatan sistem dan teknologi informasi dapat mempercepat penyusunan kombinasi bahan makanan sedemikian rupa sehingga seorang manajer di perusahaan pembuat makanan unggas dapat mengambil / membuat keputusan dalam memilih kombinasi bahan makanan pembentuk ransum unggas secara efektif [13].

Penyusunan kombinasi bahan makanan pembentuk ransum memperhatikan kandungan nutrisi bahan makanan, harga bahan makanan, dan kebutuhan nutrisi yang sesuai dengan umur dan jenis unggas [14]. Permasalahan yang dihadapi adalah bagaimana membuat ransum unggas yang baik dan ekonomis yaitu ransum yang memenuhi kebutuhan nutrisi unggas untuk hidup dan untuk berproduksi dengan memenuhi kriteria murah.

Batasan-batasan masalah dari sistem yang akan dibuat adalah unggas yang diteliti dibatasi hanya ayam ras pedaging, petelur dan ayam buras; bahan makanan dan feed supplement yang ditentukan oleh sistem merupakan bahan makanan yang sudah lazim digunakan atau feed supplement yang ada di pasaran, dan bahan makanan yang sudah diteliti kandungan nutrisinya dan mudah atau bisa didapatkan; daftar kandungan nutrisi yang terdapat dalam bahan makanan dan kebutuhan nutrisi unggas merupakan hasil penelitian terdahulu, karena penelitian yang dilakukan merupakan kajian pustaka; kebutuhan dan kandungan nutrisi yang diperhitungkan hanya nutrisi yang esensial. Kebutuhan nutrisi yang tidak terhitung dapat dipenuhi dari feed supplement atau bahan makanan tambahan.

Tujuan pembuatan sistem ini adalah untuk menemukan formula kombinasi bahan makanan yang optimal. Nilai optimal adalah kombinasi bahan makanan pembentuk ransum dengan harga serendah mungkin dengan kualitas yang memenuhi standar.

\section{LANDASAN TEORI}

Ayam dan unggas lain membutuhkan sejumlah nutrisi untuk menunjang hidup, pertumbuhan, kelangsungan keturunan, dan untuk keperluan produksinya. Sejumlah nutrisi yang dibutuhkan adalah lebih dari 40 material kimiawi yang diklasifikasikan menjadi 6 kelompok yaitu energi yang bersumber dari karbohidrat dan lemak, protein, vitamin, mineral, dan air [15]. Semuanya itu dapat dipenuhi dari makanan atau ransum. Kekurangan salah satu dari butrisi tersebut dapat menyebabkan unggas sakit / malnutrisi bahkan sampai mati, yang berakibat pada kerugian peternak. Nutrisi yang dibutuhkan meliputi protein, energi, vitamin, mineral, dan air.

\section{A. Protein}

Protein merupakan komponen organik yang kompleks, yang ditentukan oleh keseimbangan dan kelengkapan asam amino yang terkandung dalam bahan makanan dan asam amino yang dibutuhkan unggas [14]. Bahan makanan yang mengandung protein antara lain tepung ikan, bungkil kelapa, bungkil kedelai, jagung dan dedak. Protein dalam bahan makanan terkombinasi dengan karbohidrat, lemak, dan mineral sehingga bahan makanan sumber protein juga merupakan sumber karbohidrat, lemak, dan mineral [16]. Tabel I menunjukkan kebutuhan protein pada unggas.

TABEL I

TABEl KebUtUhan PROTEIN PADA UNGGAS

\begin{tabular}{|l|l|r|}
\hline Jenis Unggas & Fase Unggas & $\begin{array}{r}\text { Kebutuhan } \\
\text { Protein (\%) }\end{array}$ \\
\hline Petelur & Starter & 20,65 \\
\hline Petelur & Grower & 14,6 \\
\hline Petelur & Layer & 13,56 \\
\hline Petelur & Bertelur & 17 \\
\hline Pedaging & Starter & 22,86 \\
\hline Pedaging & Finisher & 19,61 \\
\hline Buras & Starter & 17 \\
\hline Buras & Grower & 14 \\
\hline Buras & Layer & 12 \\
\hline Buras & Dewasa & 17 \\
\hline
\end{tabular}

\section{B. Energi}

Lemak dan Karbohidrat merupakan sumber energi dan sumber panas tubuh untuk menjaga temperatur tubuh. Bungkil kelapa merupakan salah satu sumber energi yang baik selain jagung dan dedak. Energi yang dikonsumsi tidak semuanya digunakan oleh tubuh unggas [2].

Pemanfaatan energi dapat dicapai secara optimal jika kebutuhan energi sama dengan kandungan energi dalam ransum. Ransum dengan kadar energi yang melebihi kebutuhan optimal akan menghasilkan ayam yang gemuk, sedangkan ransum dengan kadar energi yang rendah akan menghasilkan ayam yang kurus. Dengan protein, mineral, dan vitamin yang seimbang, maka ransum dengan kadar energi yang tinggi maupun rendah akan menghasilkan unggas dengan bobot yang sama nilainya pada masa produksi. Kadar energi untuk unggas petelur harus diperhatikan, karena jika terlalu tinggi akan menyebabkan timbunan lemak, terutama pada organ-organ reproduksi yang akan mengakibatkan menurunnya produktifitas. Tabel II menunjukkan kebutuhan energi pada unggas. 
TABEL II

TABEL KebUtUhan ENERGI PADA UNGGAS

\begin{tabular}{|l|l|r|}
\hline $\begin{array}{c}\text { Jenis } \\
\text { Unggas }\end{array}$ & Fase Unggas & $\begin{array}{c}\text { Kebutuhan } \\
\text { Energi (kcal/Kg) }\end{array}$ \\
\hline Petelur & Starter & 2385 \\
\hline Petelur & Grower & 2750 \\
\hline Petelur & Layer & 2575 \\
\hline Petelur & Bertelur & 2000 \\
\hline Pedaging & Starter & 3015 \\
\hline Pedaging & Finisher & 3150 \\
\hline Buras & Starter & 2200 \\
\hline Buras & Grower & 2500 \\
\hline Buras & Layer & 2300 \\
\hline Buras & Dewasa & 2000 \\
\hline
\end{tabular}

\section{Vitamin}

Vitamin merupakan komponen organik yang tidak dibuat oleh tubuh, dibutuhkan dalam jumlah kecil, tetapi mempunyai peran yang besar untuk proses penting dalam tubuh. Vitamin dapat dibagi menjadi dua yaitu vitamin yang larut dalam air dan vitamin yang larut dalam lemak. Vitamin yang larut dalam air yaitu vitamin B, dan C, sedangkan vitamin yang larut dalam lemak adalah A, D, E dan K. Vitamin dapat dipenuhi dari bahan makanan hijauan dan dari feed supplement [2]. Tabel III menunjukkan kebutuhan vitamin pada unggas.

TABEL III

TABEL KEBUTUHAN VITAMIN PADA UNGGAS

\begin{tabular}{|c|r|r|r|}
\hline Vitamin & \multicolumn{3}{|c|}{ Umur / Fase Produksi Unggas } \\
\hline & $0-8$ Minggu & 8-18 Minggu & \multicolumn{1}{|c|}{ Petelur } \\
\hline A (IU) & 1500 & 1500 & 4000 \\
\hline D (IU) & 200 & 200 & 500 \\
\hline E (IU) & 10 & - & - \\
\hline K1 (mg) & 0,53 & - & - \\
\hline B1 (mg) & 1,8 & - & - \\
\hline B2 (mg) & 3,6 & 1,8 & 2,2 \\
\hline B6 (mg) & 0,09 & - & - \\
\hline B12 (mg) & 0,009 & - & - \\
\hline
\end{tabular}

\section{Mineral}

Mineral dapat digolongkan menjadi mineral makro, mineral mikro dan mineral fungsional. Mineral merupakan 3\%-5\% dari keseluruhan tubuh unggas. Mineral tidak dapat dibuat oleh tubuh unggas, sehingga harus dipenuhi dari ransum [1]. Mineral digolongkan atas mineral makro dan mineral mikro. Yang termasuk mineral makro adalah Kalsium (Ca), Fosfor (P), Natrium (Na), dan Klor (cl), sedangkan yang termasuk mineral mikro antara lain Magnesium (Mg), Mangan (Mn), Seng ( $\mathrm{Zn})$, Besi $(\mathrm{Fe})$, Tembaga (Cu), Iodum (I), Selenium (Se), Kobalt (Co), Krom (Cr), Molybdenum (Mo) [5]. Tabel IV menunjukkan kebutuhan mineral makro pada Unggas.
TABEL KebUtUHAN Mineral MaKRO PADA UnGGas

\begin{tabular}{|c|r|r|r|}
\hline \multirow{2}{*}{$\begin{array}{c}\text { Mineral } \\
\text { Makro (\%) }\end{array}$} & \multicolumn{3}{|c|}{ Umur / Fase Produksi Unggas } \\
\cline { 2 - 4 } & 0-8 Minggu & 8-18 Minggu & \multicolumn{1}{c|}{ Petelur } \\
\hline $\mathrm{Ca}$ & 1,8 & 0,6 & 3,3 \\
\hline $\mathrm{P}$ & 0,4 & 0,4 & 0,35 \\
\hline $\mathrm{Na}$ & 0,15 & 0,2 & 0,12 \\
\hline $\mathrm{Cl}$ & 0,15 & 0,1 & 0,1 \\
\hline
\end{tabular}

E. Air

Air harus tersedia setiap saat. Kekurangan air dapat menyebabkan penurunan pertumbuhan dan penyakit pengumpulan asam urat dalam jaringan tubuh unggas. Air juga berfungsi sebagai bahan pelarut nutrisi yang merupakan bagian dari transportasi dalam tubuh, dan untuk menjaga temperatur tubuh. Kebutuhan air meningkat seiring dengan kenaikan suhu lingkungan. Kebutuhan air bagi ayam petelur lebih banyak dari ayam bukan petelur [1]

\section{F. Feed Supplement}

Feed Supplement adalah bahan makanan yang berupa preparat vitamin, mineral, dan antibiotik guna melengkapi kandungan nutrisi ransum. Pemberian feed supplement bertujuan untuk mempercepat pertumbuhan, mempertahankan atau meningkatkan produksi, dan menjaga kesehatan unggas. Feed supplement dapat berbentuk vitamin saja, vitamin dan mineral, atau campuran antara vitamin, mineral, dan antibiotik. Feed supplement yang berupa vitamin saja dapat diberikan secara terus menerus, tetapi yang mengandung antibiotik harus hati-hati dalam pemberiannya, karena pemberian antibiotik yang salah akan mengakibatkan kekebalan atau resistan sehingga jika unggas sakit akan sulit sekali disembuhkan / diobati dengan antibiotik [3]. Tabel V menunjukkan contoh feed supplement yang sering digunakan untuk unggas.

TABEL V

FEED SUPPLEMENT YANG SERING DIGUNAKAN UNGGAS

\begin{tabular}{|l|c|l|l|}
\hline \multicolumn{1}{|c|}{ Jenis } & Produsen & \multicolumn{1}{c|}{ Isi } & \multicolumn{1}{c|}{ Pemakaian } \\
\hline Premix A & Pfizer & Vitamin & Anak Ayam \\
\hline Premix B & Pfizer & Vitamin & Ayam Dewasa \\
\hline TM 10 & Pfizer & Teramisin & $\begin{array}{l}\text { Pencegahan dan } \\
\text { Penyembuhan Penyakit }\end{array}$ \\
\hline Aurofac & Cynamid & Aeuromicin & $\begin{array}{l}\text { Pencegahan dan } \\
\text { Penyembuhan Penyakit }\end{array}$ \\
\hline $\begin{array}{l}\text { Rhodiamix } \\
22\end{array}$ & $\begin{array}{l}\text { Rhone } \\
\text { Poulence }\end{array}$ & Vitamin & Ayam Muda dan Bibit \\
CFT 22 & Rhone & Vitamin & Ayam Muda dan Bibit \\
\hline $\begin{array}{l}\text { Rhodiamix } \\
\text { Poulence }\end{array}$ & $\begin{array}{c}\text { Rhone } \\
\text { Poulence }\end{array}$ & Vitamin & Ayam Dewasa \\
\hline $\begin{array}{l}\text { Rhodiamix } \\
\text { CFT 273 }\end{array}$ & $\begin{array}{c}\text { Rhone } \\
\text { Poulence }\end{array}$ & Vitamin & Ayam Dewasa \\
\hline $\begin{array}{l}\text { Rhodiamix } \\
784\end{array}$ & $\begin{array}{l}\text { Rhone } \\
\text { Poulence }\end{array}$ & Vitamin & $\begin{array}{l}\text { Semua Jenis dan Umur } \\
\text { Ayam }\end{array}$ \\
\hline $\begin{array}{l}\text { Mineral } \\
\text { Whimoyer }\end{array}$ & $\begin{array}{l}\text { Mineral } \\
\text { (Ca, Fe, P, }\end{array}$ & $\begin{array}{l}\text { Semua Jenis dan Umur } \\
\text { Ayam }\end{array}$ \\
& & Mn, Zn) & \\
& &
\end{tabular}

G. Bahan Makanan 
Bahan makanan untuk unggas bermacam-macam, ada yang biasa digunakan, ada pula yang masih dalam penelitian. Di dalam pemilihan bahan makanan perlu diperhatikan kesinambungan bahan makanan, jumlah bahan makanan yang dipilih yang tergantung oleh hasil panen dari pertanian dan kebutuhan produksi ransum, kualitas bahan yang dipengaruhi oleh cara penyimpanan, asal bahan dan transportasi bahan [15].

Berdasarkan kandungan nutrisinya, bahan makanan dapat diklasifikasikan menjadi tiga yaitu bahan makanan sumber energi, bahan makanan sumber protein, dan bahan makanan tambahan. Bahan makanan sumber energi yang berasal dari tumbuhan dan limbahnya antara lain jagung, sorgum, dedak, ubi kayu, dan minyak makan. Bahan makanan sumber protein dapat diperoleh dari tumbuhan dan limbahnya antara lain bungkil kedelai, bungkil kacang tanah, bungkil kelapa, bungkil biji kapas, dan bungkil, biji matahari. Bahan makanan tambahan bersifat pelengkap, dapat berupa hijauan, sumber mineral untuk mencukupi kebutuhan kalsium, garam, gula atau tetes, serta feed supplement.

\section{H. Sistem Pakar}

Sistem Pakar merupakan bagian dari Artificial Intelligence yang mengambil atau memindahkan pengetahuan seorang ahli untuk pemecahan suatu permasalahan atau pengambilan keputusan [17]. Sistem ini mempunyai level performa yang dapat menyamai seorang pakar pada spesialisasi tertentu dan biasanya pada area khusus. Di dalam sistem pakar terdapat dua metode pelacakan yaitu Forward Chaining dan Backward Chaining [2].

Forward Chaining merupakan metode pelacakan yang dimulai dari data dan informasi yang tersedia menuju kepada suatu kesimpulan / konklusi. Dalam Forward Chaining, jika premise clause sesuai dengan situasi, maka proses akan menghasilkan atau menyatakan kesimpulan. Langkah pertama dimulai dari kondisi, gejala atau symptom, yang merupakan fakta yang menuju kepada suatu kesimpulan [2].

Sebaliknya, Backward Chaining merupakan metode pelacakan yang dimulai dari sebuah kemungkinan atau hipotesis kemudian mencari bukti yang mendukung kemungkinan untuk menemukan fakta. Jika current goal menggambarkan fakta dalm kesimpulan, maka proses akan memberikan premise clause yang sesuai dengan situasi. Dalam backward chaining, dimulai dengan mencari kondisi yang menyebabkan terbentuknya suatu kesimpulan [17].

\section{Metode Simpleks}

Pemrograman linier menggambarkan hubungan fungsi linier dalam model matematika yang terdiri dari variabel keputusan, fungsi tujuan, batasan model. Berikut ini adalah langkah-langkah yang terdapat dalam metode simpleks [18, 19].
Pertama, mengubah bentuk batasan model pertidaksamaan menjadi bentuk persamaan dengan menambahkan variabel pengurang (untuk maksimisasi dengan tanda batasan $\leq$ ) yang mencerminkan sumber daya yang tidak terpakai atau variabel penambah pada masalah minimisasi yang mencerminkan kelebihan diatas batas minimum sumber daya yang diperlukan. Yang keduanya bisa bersimbol $\mathrm{S}_{\mathrm{i}}$ dan harus bernilai non negatif. Untuk menghindari agar nilai $S_{i}$ tidak negatif, dan untuk mendapatkan solusi awal pada titik origin $\left(\mathrm{X}_{\mathrm{i}}=0\right)$ maka perlu ditambahkan sebuah variabel lagi yang disebut variabel artifisial $\left(\mathrm{A}_{\mathrm{i}}\right)$ pada persamaan batasan. Variabel $\mathrm{S}_{\mathrm{i}}$ dan $\mathrm{A}_{\mathrm{i}}$ tidak berdampak pada menaikkan atau menurunkan biaya pada fungsi tujuan karena kenaikan atau penurunan biaya ditentukan oleh variabel keputusan $\mathrm{X}_{\mathrm{i}}$ sehingga variabelvariabel tersebut dapat diberi nilai nol.

Kedua, pembentukan tabel simpleks awal model minimisasi untul solusi feasible dasar pada titik awal/origin dan menghitung nilai-nilai pada baris $\mathrm{Z}_{\mathrm{j}}$ dan baris $\mathrm{Zj}-\mathrm{Cj}$. Nilai pada baris $\mathrm{Zj}$ merupakan jumlah dari perkalian antara nilai pada kolom $\mathrm{Cj}$ dengan nilai pada kolom $\mathrm{X}_{\mathrm{j}}$ atau kolom kuantitas. Nilai $\mathrm{Cj}$ mencerminkan kontribusi biaya untuk setiap $\mathrm{Xi}$. Nilai pada baris $\mathrm{Zj}-\mathrm{Cj}$ mencerminkan penurunan biaya per unit bersih yang dihitung mengurangkan baris $\mathrm{Zj}$ dengan baris $\mathrm{Cj}$ pada baris teratas dari tabel.

Ketiga, menentukan baris pemutar atau variabel non dasar (variabel yang tidak terdapat pada solusi feasible dasar) yang masuk dengan cara memilih kolom yang mempunyai nilai positif tertinggi pada baris $\mathrm{Zj}-\mathrm{Cj}$ atau yang memiliki kontribusi terkecil terhadap biaya per unit, yang disebut sebagai kolom pemutar (pivot column). Dalam metode simpleks dari satu titik solusi berpindah ke titik sejajar, yaitu satu variabel dalam solusi feasible dasar digantikan dengan suatu variabel yang sebelumnya bernilai nol.

Keempat, menentukan baris pemutar atau variabel dasar yang keluar dengan cara membagi nilai-nilai pada kolom kuantitas dengan nilai-nilai pada kolom kuantitas dengan nilai-nilai pada kolom pemutar dan memilih baris dengan hasil bagi non negatif terkecil. Nilai pada perpotongan antara baris pemutar dengan kolom pemutar disebut sebagai angka pemutar, kemudian mencari nilai baris pemutar yang baru dengan membagi nilai baris pemutar pada tabel yang lama dengan angka pemutar.

Kelima, baris pemutar pada tabel baru dihitung dengan membagi tiap nilai dalam baris pemutar pada tabel pertama dengan angka pemutar.

\section{METODE PENELITIAN}

Setelah dilakukan analisis terhadap permasalahan dan pemecahannya, maka dibuat suatu metode penelitian untuk sistem ransum unggas.

Tahap pertama adalah dilakukan proses pengumpulan data-data yang berkaitan erat dengan jenis dan fase unggas, 
kebutuhan nutrisi unggas, bahan makanan dan kandungan nutrisi bahan makanan.

Tahap kedua adalah menginputkan jenis dan fase unggas, kemudian dilanjutkan dengan pelacakan kebutuhan nutrisi unggas. Langkah berikutnya adalah menginputkan bahan makanan yang dilanjutkan dengan penentuan kandungan nutrisi bahan makanan unggas.

Tahap ketiga adalah proses pemodelan dan perhitungan pemrograman linier dengan metode simpleks terhadap datadata yang telah dimasukkan dalam tahap kedua. Setelah dilakukan proses perhitungan, maka akan dilakukan proses pengujian terhadap hasil optimasi. Jika hasil kombinasi bahan makanan unggas optimal maka akan memberikan hasil kombinasi bahan makanan, sebaliknya jika hasil belum optimal maka dilakukan proses input data sesuai dengan tahap kedua.

Gambar 1 menunjukkan metode penelitian untuk sistem ransum unggas yang ekonomis.

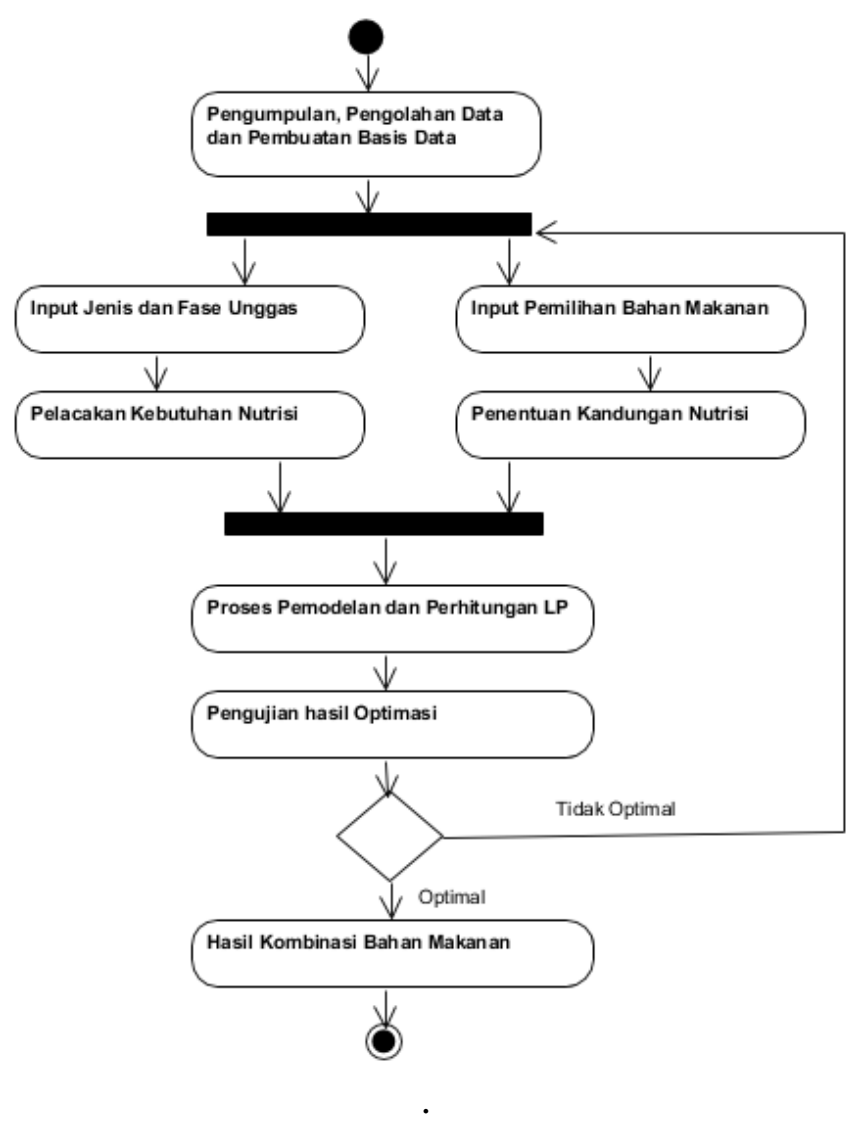

Gambar 1 Metode Penelitian

\section{A. Pelacakan Kebutuhan Nutrisi Unggas}

Untuk dapat melakukan proses pelacakan kebutuhan nutrisi unggas dan penentuan kandungan nutrisi bahan makanan maka digunakan metode forward chaining dengan rule proses pelacakan [2] sebagai berikut :
R1 IF jenis unggas=petelur AND fase=starter THEN kebutuhan energi $=2385$, protein $=21 \%, \quad \mathrm{Ca}=1,8 \%$, Serat $=5 \%$

R2 IF jenis unggas=petelur AND fase=developer THEN kebutuhan energi $=2750$, protein $=14,6 \%, \mathrm{Ca}=0,6 \%$, Serat $=6 \%$

R3 IF jenis unggas=petelur AND fase=finisher THEN kebutuhan energi $=2575$, protein $=13,56 \%, \mathrm{Ca}=0,6 \%$, Serat $=6 \%$

R4 IF jenis unggas=petelur AND fase=bertelur THEN kebutuhan energi $=2000$, protein $=17 \%, \mathrm{Ca}=3,3 \%$, Serat $=6 \%$

R5 IF jenis unggas=pedaging AND fase=starter THEN kebutuhan energi $=3015$, protein $=22,86 \%, \mathrm{Ca}=1,8 \%$, Serat $=4 \%$

R6 IF jenis unggas=pedaging AND fase=finisher THEN kebutuhan energi $=3150$, protein $=19,61 \%, \mathrm{Ca}=0,6 \%$, Serat $=4 \%$

R7 IF jenis unggas=buras AND fase=starter THEN kebutuhan energi $=2200$, protein $=17 \%, \mathrm{Ca}=1,8 \%$, Serat $=7 \%$

R8 IF jenis unggas=buras AND fase=grower THEN kebutuhan energi $=2500$, protein $=14 \%, \quad \mathrm{Ca}=0,6 \%$, Serat $=7 \%$

R9 IF jenis unggas=buras AND fase=layer THEN kebutuhan energi $=2000$, protein $=12 \%, \mathrm{Ca}=0,6 \%$, Serat $=7 \%$

R10 IF jenis unggas $=$ buras AND fase $=$ dewasa THEN kebutuhan energi $=2385$, protein $=17 \%, \mathrm{Ca}=3,3 \%$, Serat $=7 \%$

\section{B. Activity Diagram Metode Simpleks}

Proses pemodelan untuk penentuan kombinasi bahan makanan unggas yang ekonomis dilakukan dengan metode simpleks. Langkah-langkah metode simpleks dalam penentuan kombinasi bahan makanan sebagai berikut :

1. membentuk fungsi tujuan (f) yang merupakan tujuan utama dari formulasi. Bentuk umum dari fungsi tujuan sebagai berikut :

$f=c_{1} x_{1}+c_{2} x_{2}+. .+c_{n} x_{n}$

dengan :

f : fungsi tujuan dari formulasi pakan unggas yaitu meminimumkan harga

ci : koefisien harga bahan pakan

xi : jumlah bahan pakan yang digunakan

2. membentuk fungsi pembatas (xj) dari kandungan nutrisi pada bahan pakan dan kebutuhan nutrisi unggas.

$a_{11} x_{1}+a_{12} x_{2}+. .+a_{1 n} x_{n}(\leq \geq) b_{1}$

$a_{21} x_{1}+a_{22} x_{2}+. .+a_{2 n} x_{n}(\leq \geq \geq) b_{2}$

$a_{m 1} x_{1}+a_{m 2} x_{2}+. .+a_{m n} x_{n}(\leq \geq) b$

$x_{1}, x_{2}, \ldots, x_{n} \geq 0$

dengan :

$\mathrm{a}_{\mathrm{ij}}$ : kandungan nutrisi $i$ pada bahan pakan $j$

$\mathrm{x}_{\mathrm{j}}$ : jumlah bahan pakan $j$ yang digunakan

$\mathrm{b}_{\mathrm{i}}$ : kandungan nutrisi $i$ yang dibutuhkan unggas 
3. memasukkan nilai fungsi variabel slack $\left(\mathrm{S}_{\mathrm{n}}\right)$ pada fungsi tujuan dan fungsi pembatas, sehingga terbentuk fungsi kanonik.

4. menyusun persamaan-persamaan fungsi kanonik ke dalam tabel simpleks pada tabel VI.

TABEL VI

Bentuk UMUM TABEL SiMPLEKS

\begin{tabular}{|c|c|c|c|c|c|c|}
\hline & $\mathrm{C}_{\mathrm{j}}$ & $\mathrm{X}_{1}$ & $\mathrm{X}_{2}$ & 0 & 0 & 0 \\
\hline $\mathrm{Cb}$ & $\mathrm{vdb}$ & Harga $\mathrm{X}_{1}$ & Harga $_{2}$ &.. & 0 & 0 \\
\hline-1 & $\mathrm{~S} 1$ &.. &.. &.. & & \\
\hline-1 & $\mathrm{~S} 2$ &.. &.. &.. & & \\
\hline.. &.. &.. &.. &.. & & \\
\hline & $\mathrm{Zj}$ & & & & & \\
\hline $\mathrm{Cj}-\mathrm{Zj}$ & & & & & & \\
\hline
\end{tabular}

5. memilih kolom kunci dengan cara mencari nilai $\mathrm{Cj}-\mathrm{Zj}$ terbesar

6. memilih baris kunci dengan cara mencari nilai terkecil dari indeks. Nilai indeks merupakan pembagian antara nilai NK dan nilai kolom kunci.

7. mengubah nilai-nilai baris kunci dengan cara membaginya dengan angka kunci.

8. mengubah nilai-nilai selain pada baris kunci dengan cara :

baris baru = baris lama - (koefisien pada kolom kunci) * nilai baru baris kunci.

9. mengulang langkah-langkah perbaikan mulai langkah ke-5 sampai langkah ke-8 hingga nilai-nilai pada baris $\mathrm{Cj}-\mathrm{Zj}$ tidak ada yang bernilai negatif.

Gambar 2 dan 3 menunjukkan algoritma metode simpleks yang disajikan dalam activity diagram.

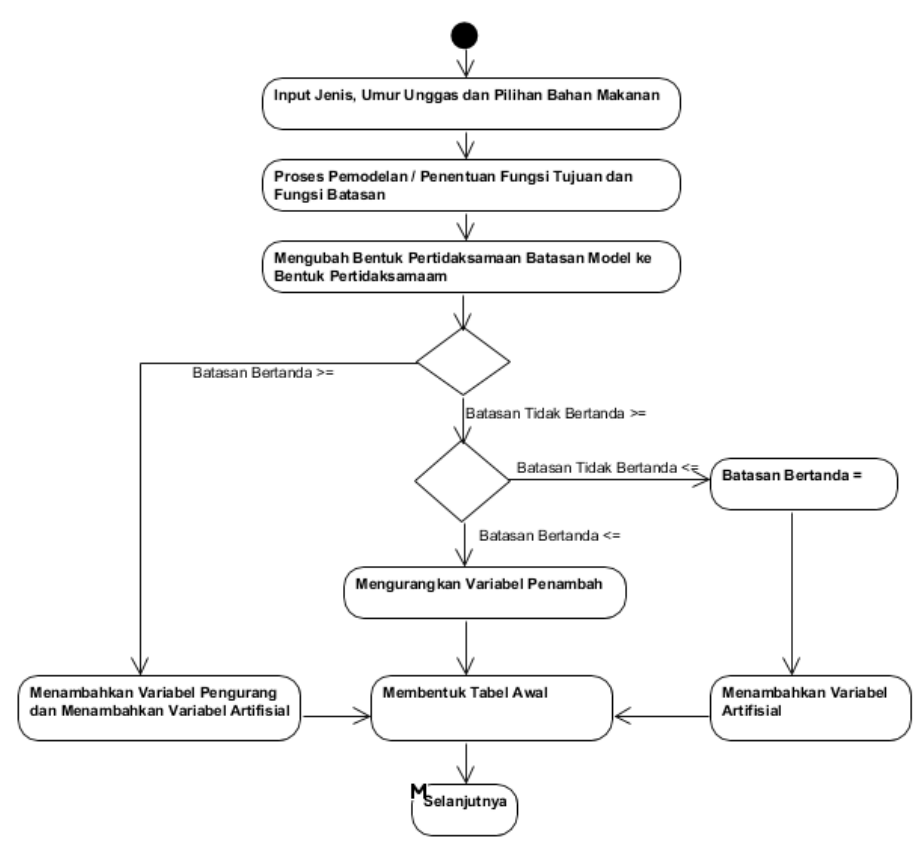

Gambar 2 Algoritma Metode Simpleks

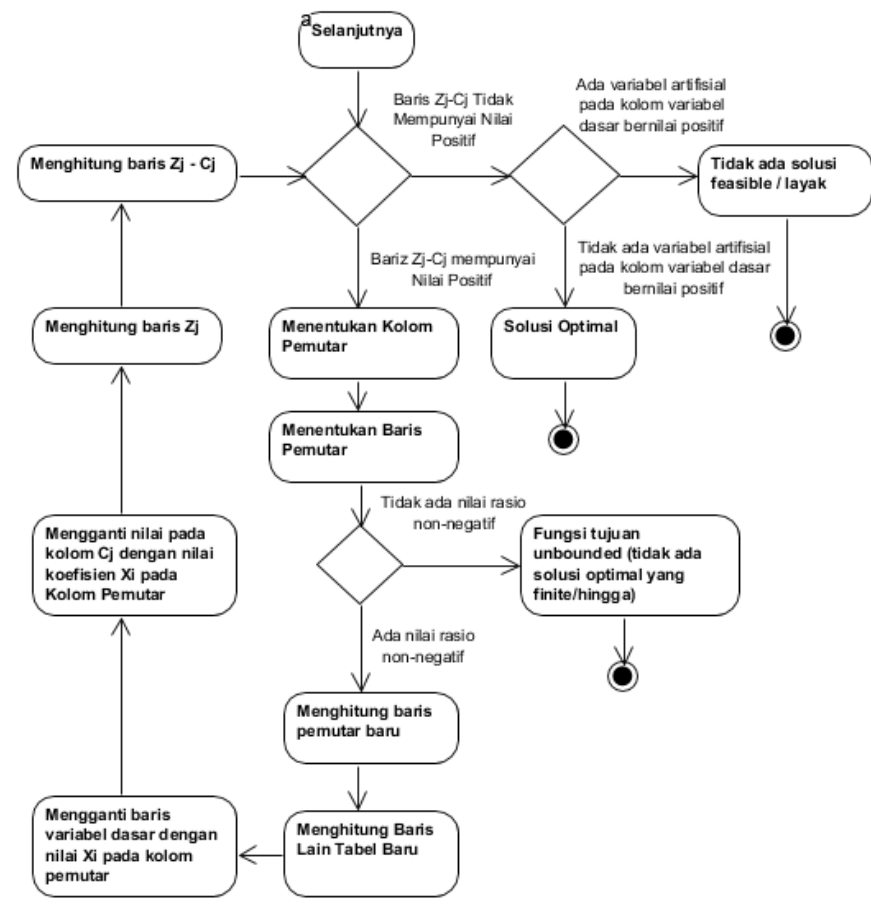

Gambar 3 Algoritma Metode Simpleks (Lanjutan)

\section{HASIL DAN PEMBAHASAN}

\section{A. Analisis dan Desain Sistem}

Didalam sistem ransum unggas terdapat enam use case yang digunakan untuk menentukan kombinasi bahan makanan yang ekonomis yang terbagi dalam dua bagian yaitu use case yang berkaitan dengan proses pelacakan dengan metode forward chaining dan use case yang berkaitan dengan proses penentuan kombinasi makanan dengan menggunakan metode simpleks. Use case bagian pelacakan terdiri atas use case pelacakan penentuan jenis unggas dan fase unggas; dan use case pelacakan penentuan kebutuhan nutrisi unggas. Selanjutnya, use case bagian penentuan kombinasi bahan makanan terdiri atas use case pencocokan penentuan kombinasi ransum unggas; use case pencocokan penentuan kandungan nutrisi unggas; use case perhitungan harga pakan; dan use case perbandingan harga pakan. Gambar 4 menunjukkan use case diagram untuk sistem ransum unggas. 


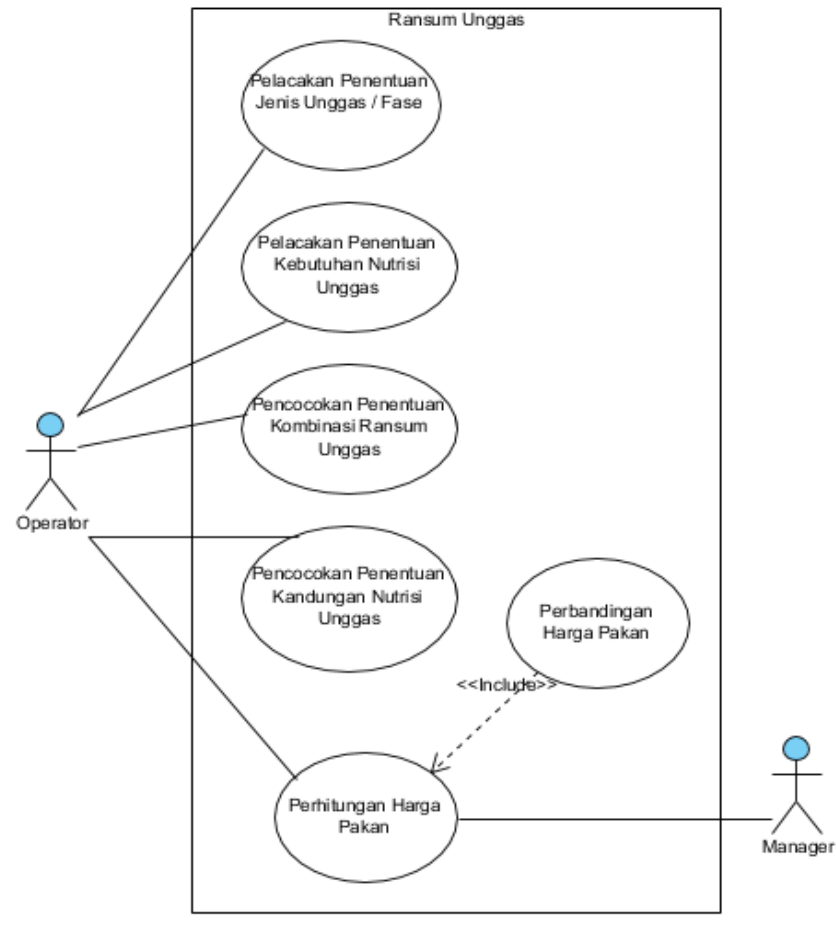

Gambar 4 Use Case Diagram Sistem Ransum Unggas

Terdapat delapan class yang digunakan untuk sistem ransum unggas yaitu Unggas, Fase, Detil Fase, Nutrisi, Bahan Makanan, Detil Bahan Makanan, Pakan Jadi, Detil Pakan Jadi. Kedelapan class tersebut dibagi menjadi dua bagian yaitu class yang menyimpan data pokok tentang unggas, bahan makanan, dan nutrisi, sedangkan bagian kedua yaitu class yang menyimpan data transaksi yang berkaitan dengan fase unggas, detil fase unggas, pakan jadi, detil pakan jadi, dan detil bahan makanan. Rincian kedua bagian Class adalah sebagai berikut.

Bagian pertama yaitu Class Unggas yang digunakan untuk menyimpan data pokok unggas; Class Nutrisi yang digunakan untuk menyimpan data kandungan nutrisi makanan; Class Bahan Makanan yang digunakan untuk menyimpan data bahan makanan termasuk harga beli bahan tersebut.

Bagian kedua yaitu Class Fase yang digunakan untuk menyimpan fase yang terdapat pada setiap unggas; Class Detil Fase yang digunakan untuk menyimpan nutrisi yang dibutuhkan untuk unggas pada setiap fase; Class Pakan Jadi yang digunakan untuk menyimpan informasi pakan jadi untuk unggas pada setiap fase; Class Detil Pakan Jadi yang digunakan untuk menyimpan informasi kandungan nutrisi yang terdapat setiap pakan jadi; Class Detil Bahan Makanan yang digunakan untuk menyimpan informasi kandungan nutrisi yang terdapat dalam bahan makanan.

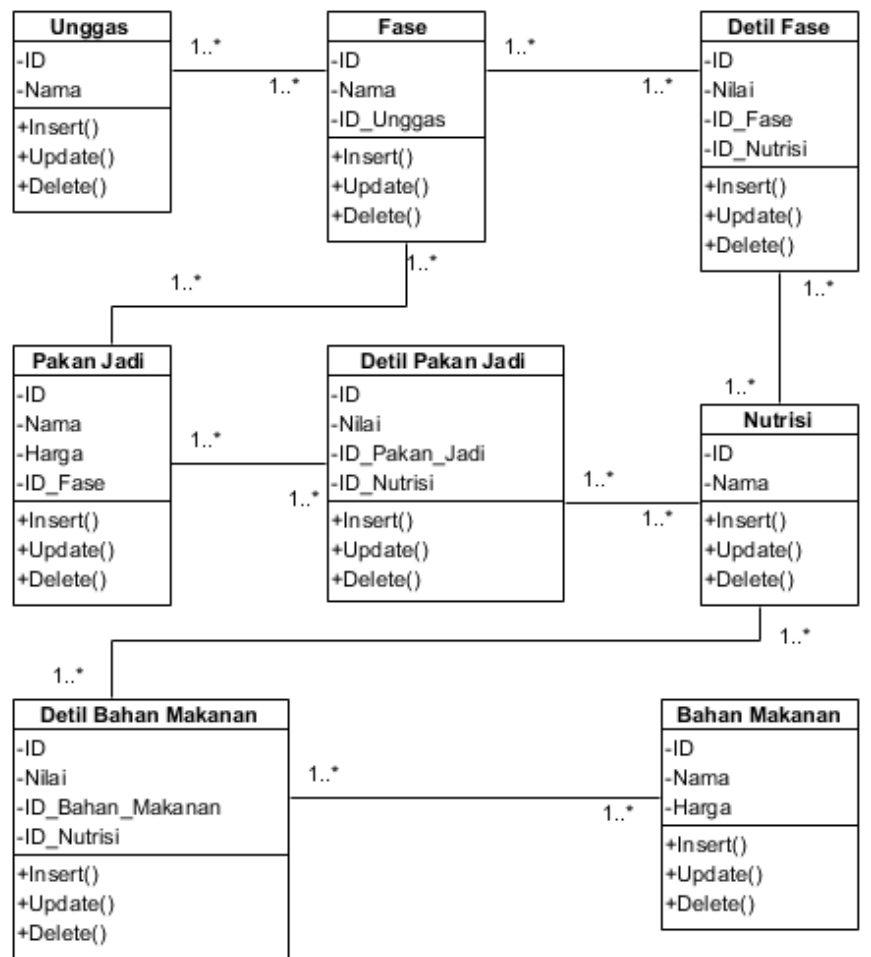

Gambar 5 Class Diagram Ransum Unggas

\section{B. Implementasi Sistem}

Form bahan makanan digunakan untuk menyimpan ID bahan makanan unggas beserta nama dan harga bahan makanan unggas tersebut. Gambar 6 menunjukkan form bahan makanan unggas.

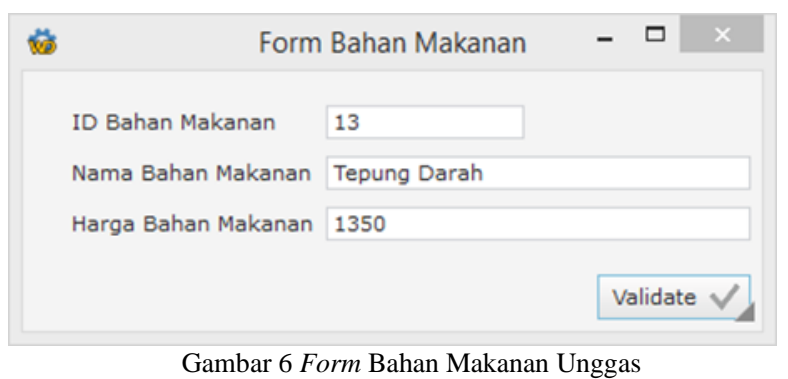

Form fase unggas digunakan untuk menyimpan identitas fase unggas beserta nama fase untuk setiap unggas. Gambar 7 menunjukkan form fase unggas. 


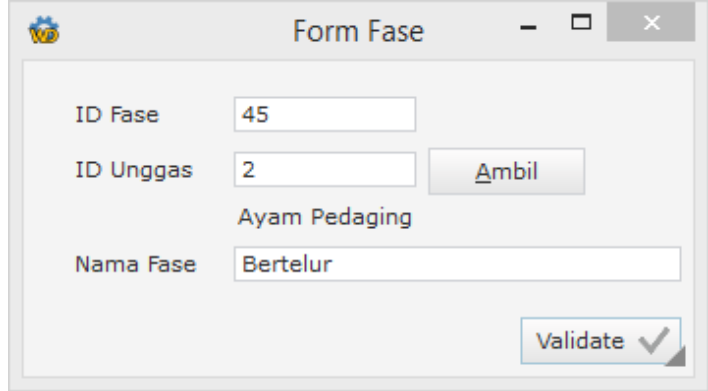

Gambar 7 Form Fase Unggas

Form unggas digunakan untuk menyimpan data pokok identitas unggas beserta nama unggas. Gambar 8 menunjukkan form master unggas.

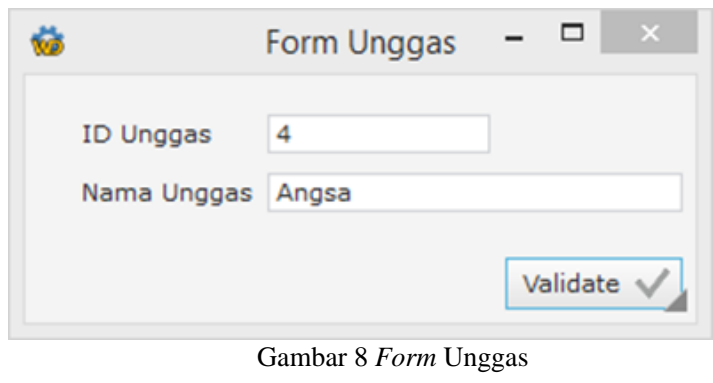

Form nutrisi digunakan untuk menyimpan data pokok identitas nutrisi beserta nama nutrisi. Form 9 menunjukkan form master nutrisi unggas.

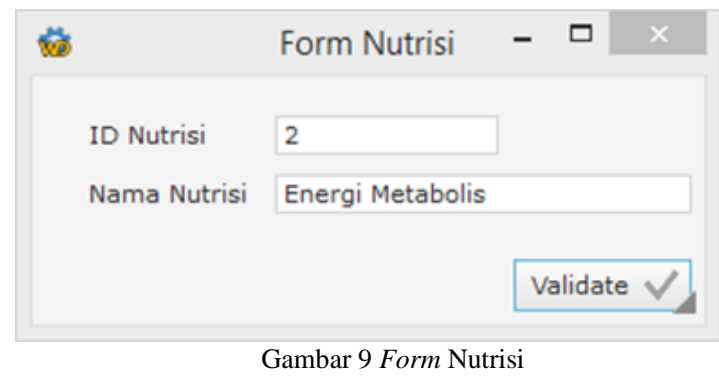

Form pakan jadi digunakan untuk menyimpan data pakan jadi meliputi identitas pakan jadi beserta namanya, identitas fase unggas dan harga pakan jadi tersebut. Gambar 10 menunjukkan form pakan jadi unggas.

\begin{tabular}{|c|c|c|c|c|}
\hline 6 & \multicolumn{2}{|c|}{ Form Pakan Jadi } & \multirow[t]{2}{*}{ - $\square$} & \multirow[t]{2}{*}{$x$} \\
\hline ID Pakan Jadi & 10 & & & \\
\hline Nama Pakan Jadi & BR19 & & & \\
\hline \multirow[t]{2}{*}{ ID Fase } & 9 & Ambil & & \\
\hline & Ayam Buras & \multirow[t]{3}{*}{ Dewasa } & & \\
\hline \multirow[t]{2}{*}{ Harga Pakan Jadi } & 7500 & & & \\
\hline & & & Valida & $\checkmark$ \\
\hline
\end{tabular}

\section{Gambar 10 Form Pakan Jadi}

Form detil bahan makanan digunakan untuk menyimpan detail bahan makanan unggas meliputi identitas bahan makanan unggas untuk setiap identitas bahan makanan unggas, identitas nutrisi, dan nilai detil bahan makanan tersebut. Gambar 11 menunjukkan form detil bahan makanan unggas.

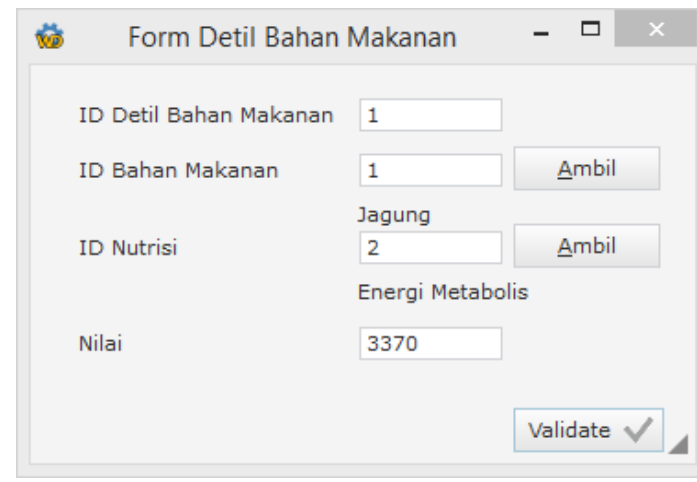

Gambar 11 Form Detil Bahan Makanan

Form detail fase digunakan untuk menyimpan data detail fase unggas meliputi identitas detail fase unggas, identitas unggas, identitas nutrisi, dan nilai. Gambar 12 menunjukkan form detail fase.

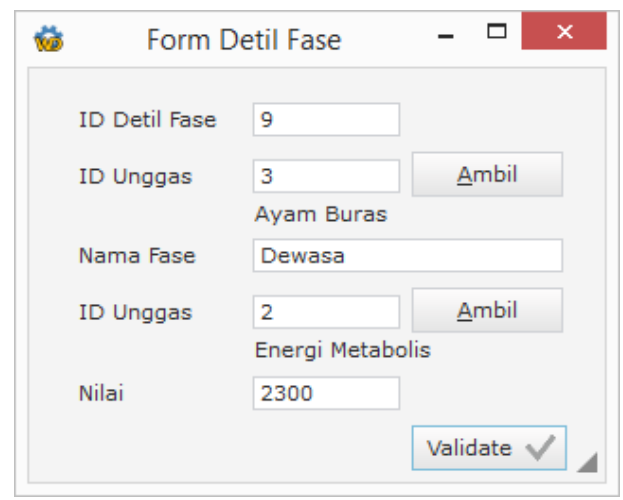

Gambar 12 Form Detail Fase

Form detail pakan jadi digunakan untuk menyimpan data detil pakan jadi meliputi identitas detil pakan jadi, identitas pakan jadi, identitas fase unggas, identitas kandungan nutrisi. Gambar 13 menunjukkan form detail pakan jadi. 


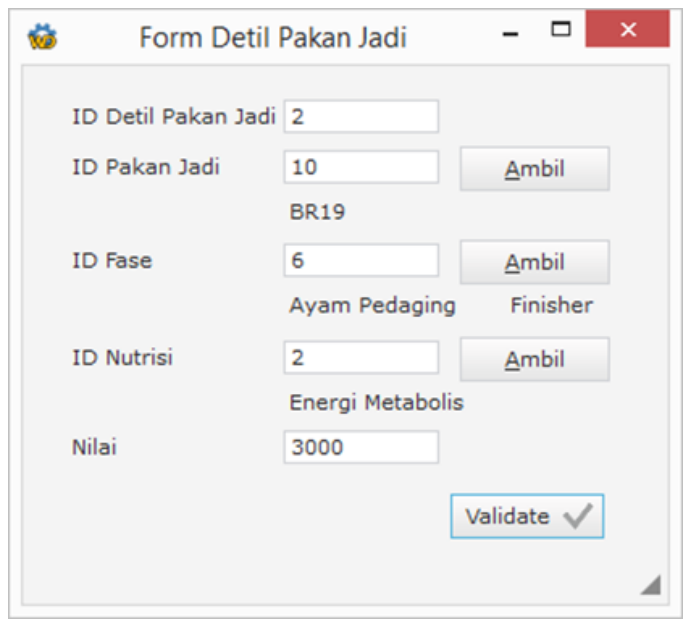

Gambar 13 Form Detail Pakan Jadi

Form kombinasi bahan makanan merupakan form yang berfungsi untuk menentukan jenis dan fase dari unggas dengan memilih combobox jenis dan combobox fase pada groupbox unggas. Setelah menentukan jenis dan fase unggas maka akan ditampilkan informasi kebutuhan nutrisi dari unggas yang terpilih, memilih bahan makanan pada checkbox yang telah tersedia tersedia, setelah dilakukan pemilihan akan ditampilkan model awal persamaan batasan dan pada textbox akan ditampilkan tabel proses perhitungan. Jika hasil optimal maka status bahan menunjukkan sudah optimal maka akan ditampilkan form hasil yang memuat informasi mengenai hasil dari perhitungan kombinasi bahan makanan sehingga terbentuk suatu komposisi bahan makanan pembentuk ransum unggas untuk jenis dan fase dari unggas sesuai dengan pilihan, harga, kandungan nutrisi dari komposisi bahan makanan untuk kategori unggas tertentu. Gambar 14 menunjukkan form kombinasi bahan makanan

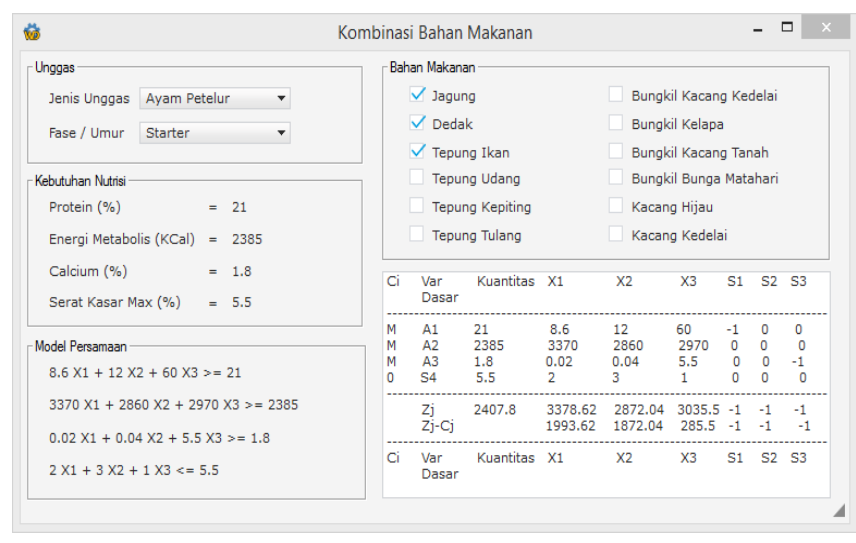

Gambar 14 Form Kombinasi Bahan Makanan

\section{Pembahasan}

Dari form kombinasi bahan makan dapat dihitung bahwa untuk jenis unggas ayam petelur fase starter dengan kebutuhan bahan makanan jagung, dedak, dan tepung ikan maka nutrisi protein yang dibutuhkan sebesar $21 \%$, energi metabolis yang dibutuhkan sebesar $2385 \mathrm{KCal}$, calcium yang dibutuhkan sebesar 1,8\% dan serat kasar sebesar 5,5\%. Bahan makanan Jagung memberikan kebutuhan nutrisi 8,6\% protein, $3370 \mathrm{KCal}$ energi metabolis, $0,02 \%$ calcium, dan $2 \%$ serat kasar. Dedak memberikan kebutuhan nutrisi $12 \%$ protein, $2860 \mathrm{KCal}$ energi metabolis, 0,04\% calcium, dan $3 \%$ serat kasar. Tepung ikan memberikan kebutuhan nutrisi $60 \%$ protein, $2970 \mathrm{KCal}$ energi metabolis, 5,5\% calcium, dan $1 \%$ serat kasar. Harga jagung di pasaran Rp. 4.000,-, harga dedak Rp. 2.300,- dan harga tepung ikan Rp. 7.500,-. Dengan menggunakan persamaan kombinasi bahan makanan diperoleh biaya untuk kombinasi ransum unggas sebesar 3.572,37 dengan bahan makanan yang digunakan adalah dedak dan tepung ikan. Kombinasi ransum unggas yang digunakan yaitu $0,5 \mathrm{~kg}$ dedak dicampur dengan $0,3 \mathrm{~kg}$ tepung ikan tetapi sudah mencukupi untuk kebutuhan nutrisi unggas untuk protein, energi metabolis, calcium, dan serat kasar.

\section{KESIMPULAN}

Sistem dapat melakukan proses pelacakan kebutuhan nutrisi unggas berdasarkan jenis dan fasenya. Dari proses tersebut dihasilkan kebutuhan nutrisi unggas berupa kebutuhan protein, energi metabolisme, kalsium, dan kemampuan unggas dalam mencerna serat yang terkandung dalam bahan makanan. Proses pemilihan bahan makanan yang dilakukan oleh user dapat menghasilkan model matematis. Selanjutnya oleh sistem dilakukan proses perhitungan yang menghasilkan kombinasi bahan makanan pembentuk ransum unggas tanpa menginputkan data keofisien dari fungsi-fungsi persamaan untuk melakukan proses perhitungan sehingga user yang merupakan manager pabrik dapat membuat keputusan yang efektif. Dari kombinasi bahan makanan akan dihasilkan biaya yang dikeluarkan untuk pembelian bahan makanan.

\section{DAFTAR PUSTAKA}

[2] M. Rasyaf, Makanan Ayam Broiler. Yogyakarta: Kanisius, 1994 [3] T. Sudaryani and S. Hari, Pembibitan Ayam Ras. Jakarta: Penebar Swadaya, 1994.

[4] G. G. Maradon, R. Sutrisna, and Erwanto, "Pengaruh ransum dengan kadar serat kasar berbeda terhadap organ dalam ayam jantan tipe medium umur 8 minggu," Jurnal Ilmiah Peternakan Terpadu, vol. III, no. 2, pp. 6-11, 2015.

[5] M. Hilmi and Taufiq, "Sistem informasi produksi ternak dan pakan unggas pada dinas peternakan propinsi Kalimantan Selatan berbasis web," Progresif, vol. XIV, no. 2, pp. 137-146, 2018.

ransum unggas," Inti Talafa, vol. VII, no. 2, pp. 31-39, 2015.

[7] T. Retnasari, "Pengembangan database untuk analisa pembuatan pakan," JIEET, vol. II, no. 2, pp. 76-84, 2018. 
[8] S. Ardhi \& H. Sutiksno, "Penerapan metode simpleks untuk optimasi jumlah kalori makanan yang dibutuhkan dalam menu diet," SMATIKA, vol. VIII, no. 1, pp. 40-49, 2018.

[9] N. L. G. P. Suwirmayanti, "Aplikasi Optimalisasi Produksi Menggunakan Metode Simpleks Berbasis Web," Techno.Com, vol. XVII, no. 1, pp. 61-69, 2018.

[10] P. Adinegoro, R. R. M. Putri, and D. E. Ratnawati, "Optimasi biaya pemenuhan asupan gizi pada makanan bagi anak-anak menggunakan metode simpleks dua fase," JPTIIK, vol. I, no. 10, pp. 1110-1119, 2017.

[11] Y. Prabowo, "Sistem pakar untuk menentukan penyakit dengan gejala kaki bengkak menggunakan forward chaining," Jurnal Teknologi Informasi dan Sistem Informasi, vol. III, no. 3, pp. 433-447, 2017.

[12] D. Febiani, "Sistem informasi formulasi ransum pakan unggas menggunakan linear programming," Skripsi Sarjana, Departemen Ilmu Komputer Fakultas Matematika dan Ilmu Pengetahuan Alam, Institut Pertanian Bogor, Bogor, 2016.

[13] N. S. Muzayyanah, "M-POLFO : sistem pakar formulasi pakan unggas menggunakan metode linear programming," Skripsi
Sarjana, Departemen Ilmu Komputer Fakultas Matematika dan Ilmu Pengetahuan Alam, Institut Pertanian Bogor, Bogor, 2013.

[14] H. Hartadi, S. Reksohadiprojo, and A. D. Tillman, Tabel Komposisi Pakan untuk Indonesia. Yogyakarta: UGM University Press, 2017.

[15] M. Rasyaf, Bahan Makanan Unggas di Indonesia. Yogyakarta: Kanisius, 1990.

[16] N. F. Hasjidla, I. Cholissodin, and A. W. Widodo, "Optimasi komposisi pakan untuk memenuhi kebutuhan nutrisi ayam petelur dengan biaya minimum menggunakan improved particle swarm optimization (IPSO)," Jurnal Pengembangan Teknologi Informasi dan Ilmu Komputer, vol. II, no. 1, pp. 1-10, 2018.

[17] D. Delen and E. Turban, Business Intelligence, Analytics, and Data Science : A Managerial Perspective. New York: Pearson, 2018.

[18] W. L. Winston, Practical Management Science. Boston: Cengage Learning, 2018.

[19] B. W. Taylor, Introduction to Management Science. New York: Pearson, 2017. 